\title{
Formation Of Joint Investigation Teams Between States, And Their International And National Legal Basis
}

\author{
Dilshod Egamberdiev , Tashkent State University of Law, Republic of Uzbekistan , d.egamberdiev@tsul.uz
}

\begin{abstract}
In recent years, the international community has developed and opened for signature a number of international agreements regulating international cooperation in the fight against crime. Along with the legal regulation of traditional legal institutions, such as mutual legal assistance in criminal matters, these instruments provide an international legal framework for new areas of cooperation in this field. One of them is the operational-investigative group or the international investigation teams. The organization of such types of investigation and joint activities of States is one of the most effective forms of interaction between interrogators, investigative bodies and law enforcement agencies, as well as other state bodies in the field of crime prevention and investigation. The Institute of joint investigations and joint interrogative teams is one of the new directions of international cooperation in the field of criminal justice, which requires detailed research. The structure of such interrogative groups simplifies the procedure for seeking legal assistance in criminal cases, helps to eliminate problems with the collection and evaluation of evidence, and so on. In this article, the author has scientifically justified the effectiveness and positive results of the activities of operational search groups, international investigative teams under international law. Comments were also made on the further development of this activity.
\end{abstract}

Keywords: international investigative group, joint investigative teams, joint investigation, Convention, Europol, crime, legal aid, investigation, group, contract, prosecutor.

$\begin{array}{lll}\text { Received: 05.12.2020 Accepted: 20.01.2021 } & \text { Published: 03.02.2021 }\end{array}$

\section{INTRODUCTION}

The emergence of difficulties and threats in the modern world, that is, the internationalization of crime, the territorial expansion of various illegal activities and the involvement of citizens of different countries in criminal organizations (criminal schemes), this inevitably leads to the development of various tragedies. This, in turn, requires the introduction of effective interstate mechanisms to combat them. The problems of the new generation, such as international terrorism, drug and arms trafficking, sexual exploitation of women and children, as well as social factors, which threaten the world community today, are directly related to the specifics of the fight against international crime. The steady growth in the scale and structure of transnational crime is a clear indication that the efforts of single countries have not yielded significant results in the fight against international crime. It is known that in the fight against crimes of an international nature, a single state does not give significant results in the fight against crimes of an international nature, due to the fact that there are barriers in the implementation of actions such as gathering evidence and applying crime prevention measures. Close cooperation between different states in all aspects is very important in the fight against transnational crime. Today, new forms of international cooperation have appeared in the provision of mutual legal assistance in criminal matters between the states, such as the organization of "operational search group", "operational investigation team", "international investigation group" and "joint investigation teams (JIT)". [1]. JITs are believed to be one of the most powerful modern tools in the fight against organized transnational crime. JITs are a means of international cooperation between the competent authorities and law enforcement agencies of two or more states, established for a limited period of time and for specific purposes (investigation of crimes committed in the territories of participating States and organized crime). On November 29, 1985, the VII session of UN General Assembly approved Milan Action Plan, by Resolution 40/32, on Crime Prevention and Treatment of Offenders [2]. The Milan Action Plan approved is noted as a useful and effective tool for strengthening international cooperation in the field of crime prevention and criminal justice. We can see that the Action Plan puts forward a number of recommendations to improve the legal regulation of the administration of justice, the need to improve the methods and techniques of cooperation in criminal investigation, the development of new mechanisms for such cooperation.

The ideas contained in the Caracas Declaration [3] and Milan Action Plan, in our view, served as a starting point for cooperation in criminal cases, one of which laid the foundation for the development and legal regulation of a number of new areas of international cooperation in criminal justice, one of which is the joint investigation institute. Compared to the traditional form of cooperation in the fight against 
crime, data and evidence can circulate freely in JITs. This in turn requires less formality than traditional collaboration, and crime investigations are carried out in a timely manner. For these reasons, the establishment of joint investigations is a very effective tool for cooperation, which facilitates the coordination of investigations and criminal cases conducted in parallel in several countries.

\section{DISCUSSION \\ JOINT INVESTIGATION TEAMS OR OPERATIVE INVESTIGATION GROUPS}

In the scientific literature, [4] the reports of practitioners [5], the reports of international anti-crime organizations [6], it is emphasized that joint investigation and operational teams (i.e., groups consisting of representatives of different states) should be set up and operated to detect and interrogate crimes committed by organized criminal groups. It should be noted that in the history of the fight against crime, there were cases when special international commissions of investigation were set up, but the subject of their investigation was international crimes and crimes of an international nature committed in the same region (Yugoslav Commission 1993, Rwanda 1994, Somalia 1993, Burundi 1995). The activities of any of these commissions did not lead to the expected results, at least in the area of criminal prosecution for violations of international humanitarian law, because even if the investigation was successful, the issue of using such findings in subsequent investigations had not been resolved [7]. Unlike the international commissions of investigation mentioned above, the establishment of joint investigation groups is primarily aimed at prosecuting crimes committed by organized criminal groups of a transnational nature.

The purpose of establishing a "joint investigation group" or "operational investigation group" is to cooperate in the detection and investigation of international transnational crimes, conducting operational search activities and presenting the necessary evidence [8]. The groups in this category can also be called "international investigation teams". Here, mainly, the crime is committed through a crossborder nature, the rapid exchange of information in the collection or retrieval of evidence, and the joint action of the competent authorities of the states. These events are formalized by special interstate agreements [1]. Organization and working with these groups has many unique advantages depending on the specific circumstances of a particular job. Conny Rijken listed the following advantages of forming these groups:

$>$ management of joint interrogative actions and operations by one person;

$>$ the requesting information from the competent authorities of the participating States may be requested directly by the member of the joint investigation group without formal requests and the information obtained from the participating states may be used directly by the group;

$>\quad$ opportunity for rapid exchange of information between member states of the group [10].

I would also like to list a few more advantages of formation of joint investigation teams, taking into account the opinion of Conny Rijken.

They are:

$>$ making quick organizational decisions;

$>$ integrated use of forces and resources of interrogators and operational search staff;

$>$ The possibility of direct participation of members of the group in the implementation of investigation actions in the jurisdiction of the states that formed the group by agreement.

$>$ Coordination of ongoing efforts, as well as the possibility of informal exchange of specialized knowledge. and work practices.

Ability to build and strengthen mutual trust between practitioners in different jurisdictions

$>$ Participation in a joint investigation team will greatly contribute to improving management skills and the ability to conduct investigations in the international arena.

We can see many different theoretical and practical concepts and definitions, expressed by the term "joint investigation team". We rarely see definitions given to investigation group formed in the international arena. However, we can still follow the definitions given by legal scholars to investigation groups set up within the state. A.Ya.Dubinsky and Yu.I. Shostak revealed the essence of the operative investigation group by identifying its characteristic features [11]. According to L.M.Karneeva, this is "a universal organizational form of cooperation that is acceptable in the investigation of any crime and is very effective at every stage of the proceedings [12].

S.V.Bajanov was one of the first to formulate a definition for the joint investigation group. In his view, joint investigation team are an organizational and procedural structure of police interrogators and forces with a clear purpose, place and time, which allows for the joint opening and investigation of complex and large-scale criminal cases on extremely dangerous crimes under the leadership of the interrogator who accepted the case [13]. The author's definition seems to be so simple that it does not fit into today's modern joint investigation team. This is because in modern investigation groups, not only 
police investigators and operational search officers, but also law enforcement interrogators from each state can participate directly as members of the group. In our view, the above proposal, in turn, unreasonably reduces the scope of crimes that joint investigation teams can interrogate.

Typically, international investigation teams are formed operatively, comprehensively, and fully detect and interrogate crimes that affect the interests of different states. According to P.A.Litvishko, the international investigation team is "optimizing the collection of evidence in criminal cases on the territory of two or more states; in the execution of a lengthy and complex procedure of gathering evidence and applying for legal assistance; to ensure the validity of the evidence obtained" [14]. This view seeks, albeit briefly, to clarify the objectives of operative investigation teams formed under international law. Because, as mentioned above, the main purpose of organization of these groups is to serve the timely investigation of crimes, the prevention of the destruction of evidence, and the application of reasonable criminal liability.

A.Yu.Svetkov, contrary to the opinion of P.A.Litvishko, puts forward such an opinion, that "the institution of the formation of international joint teams includes two important limitations. One of them is that the formation of such groups can be costly, only if a large number of criminal acts are committed in the territory of another state, and the bulk of the evidence is available in the territory of that state. Second, the activities of international joint investigation teams can be seen as a violation of state sovereignty [15]." In objection to the author's opinion, we believe that no crime should be ignored and that anyone who commits a crime shall be punished. The establishment of international investigation teams is an acceptable form of crime detection and investigation, which in turn helps to overcome the many difficulties that arise in providing legal assistance in criminal cases. Also, information is shared by the crime investigation groups in direct agreement during the investigation process, which simplifies the exchange of information. This does not affect the sovereignty of the state. It is clear from the above definitions that the joint investigation teams have scientific theoretical definition. The concept of joint investigation teams, which in our opinion is not defined in the national legislation of the Republic of Uzbekistan, should be developed. According to Article 1 of the Agreement on the Formation and Activities of Joint Investigation Teams in the Commonwealth of Independent States [16], the Joint investigation team consists of two or more national investigation and operational investigation teams of the Parties, by agreement of the central competent authorities of the parties". Based on the above definitions, it would be appropriate for international operational investigation groups to be defined as follows. "The international operative investigation group is a joint team organized by the agreement of the central investigation offices of two or more countries, which carry out urgent procedural actions in the investigation of serious or very serious crimes of national, social, economic and political significance. is a group of structured investigators, search-and-rescue officers and other. Their activities are regulated by international instruments and national legislation of the states, as well as by an agreement (contract) concluded by mutual consent of the investigation authorities".

\section{INTERNATIONAL LEGAL REGULATION OF JOINT INVESTIGATION TEAMS.}

In the rapidly developing era of telecommunications, it is unfortunate not to know about the actions, operational news and international investigation teams, their news and their general nature, due to their unfamiliarity with international legal norms and legal acts governing their actions. Cooperation between states and their law enforcement agencies in the fight against crime is mainly regulated by multilateral and bilateral agreements.

The most important international agreements in the field of combating organized crime, mutual legal assistance between states, the establishment of international investigation teams include:

Convention for the Suppression of Transnational Organized Crime, approved by Resolution 55/25 of 15 September 2000 at the 62nd Plenary Session of the 55th Session of the UN General Assembly; Convention against Corruption, approved by Resolution No. 58/4 of the 51st Plenary Session of the 58th Session of the UN General Assembly on October 31, 2003;

European Convention on Mutual Assistance in Criminal Matters among the Member States of the European Union of 29 May 2000;

Convention on Legal Assistance and Legal Relations in Civil, Family and Criminal Matters (Chisinau, 10/7/2002);

Agreement on the Procedure and Activity of Formation of Mutual Investigation Groups in the Territory of the CIS Member States "(October 16, 2015); 2001)

Shanghai Convention on the Suppression of Terrorism, Separatism and Extremism (June 15,

Along with these international acts, there are bilateral and multilateral agreements on legal assistance to the Republic of Uzbekistan in criminal matters. These international norms specify the norms 
for the formation and operation of operational investigation teams directly among states. Article 19 of the UN Convention against Transnational Organized Crime stipulates that States Parties concerned in criminal matters may conduct joint investigation and form interrogative bodies on the basis of multilateral and bilateral treaties and agreement [17]. This Convention shall apply to the investigation and prosecution of the following offenses:

$\checkmark \quad$ legalizing income came out from criminal activities;

$\checkmark$ corruption;

$\checkmark \quad$ impeding the administration of justice;

more.

$\checkmark \quad$ serious crimes - crimes punishable by imprisonment for a term of at least four years or

Article 49 of the UN Convention against Corruption states that "the Convention provides for the formation of bilateral or multilateral agreements by States to establish joint investigation team to interrogate transnational crimes covered by this Convention" [18]. At the same time, the Convention imposes an obligation to ensure the sovereignty of the countries participating in the investigation team formed among states. However, the Convention does not contain any provisions on the procedure for establishing an investigation team and its activities.

Article 18 of the Shanghai Cooperation Organization Counter-Terrorism Convention stipulates that persons who have committed crimes under the Convention, suspects or accused persons shall be detained in the territory of another State after obtaining the consent of the competent authorities of that State. may be sent to participate in operational search activities and interrogative actions [19].

In May 2000, the Council of the European Union adopted the Convention on Mutual Assistance in Criminal Matters of the Member States of the European Union. [20]. Part 1 of article 13 of the Convention stipulates that "by mutual agreement the competent authorities of the Parties may establish joint investigation groups to interrogate crimes in the territory of one or more Member States". At the same time, the Convention does not limit the investigations that can be carried out by such groups, we can also see that law enforcement and other bodies have the right to decide on the need to act together in each case. Also, in accordance with Article 5 of the Resolution on the Establishment of the European Police Agency (Europol) of 6 April 2009, one of its tasks is to require the competent authorities of the Member States to initiate, conduct and coordinate investigations and, in certain cases, to establish joint investigation teams. Such investigation teams consisted of a direct leader, members, and members attached to a joint investigation team [21].

Articles 20, 21, 22 of the Second Protocol to the European Convention on Mutual Legal Assistance in Criminal Matters, adopted on 8 November 2001 [22], are directly aimed at establishing joint operational investigation teams between states. The protocol serves as the legal basis for the establishment of a JIT by agreement between states if criminal offenses require complex investigation or if a large part of the crime is being investigated in another state. Article 20 of the Protocol states, "by mutual agreement, the competent authorities of two or more parties may establish JIT for a specific purpose and for a limited period of time, which may, by mutual agreement, conduct criminal investigations in one or more parties. The composition of the group will be determined by the contract".

The formation of investigation group and their activities is not a common practice. However, the activities of investigation groups are very effective when crimes are committed against the interests of states. For example, in October 2002, Italian police and Europol launched Operation Sunflower 2, a joint operation to combat human trafficking, involving more than 1,000 police officers from EU countries, as well as their counterparts in Russia, Ukraine and Belarus. According to police, the largest police operation in European history, 80 people have been arrested on charges of links to criminal groups that smuggle women from the eastern part of the continent to Western Europe and actually sell them into sexual slavery [23]. We may also see cases where some CIS countries have allowed foreign procedural authorities to conduct inspections in their territories.

An example of a successful collaboration is murder of a passenger Levin and the criminal case on an IL-62 that forced him to land in Ashgabat to injure Ivanov as a result of an altercation between them on October 2, 1996.

In agreement with the leadership of the Prosecutor General's Office of Turkmenistan, it was decided to send an investigation group of the Prosecutor's Office of the Russian Federation to Ashgabat.

He carried out all the necessary interrogative actions on the territory of Turkmenistan and returned to Novosibirsk together with the arrested Ivanov, Yazvenko, the victim Yaremenko [24].

The formation and regulation of international joint and investigation groups can also be observed in the national legislation of the countries of Europe and America.

In particular, Article $540^{2}$, Section $1^{2}$ of the Criminal Procedural Code of the Republic of Moldova states: 
"At least the competent authorities of the two countries may, by mutual consent, establish joint operational investigation teams to conduct criminal investigation in one or more countries for a limited period of time, which may be extended for a specific purpose and by mutual consent. The composition of the joint investigation team shall be determined by mutual consent of the parties [25]".

Criminal Procedural Code of the Kingdom of the Netherlands Part X International Mutual Legal Assistance stipulates formation of international JITs. Section 552 of this chapter states, "In order to implement the provisions of the Treaty or the framework decision of the Council of the European Union, the State Prosecutor may, for a limited period of time, set up a joint investigation team with the competent authorities of other countries. The State Prosecutor shall agree in writing with the officials of the competent authorities of the respective countries to form a joint investigation team" [26].

Additional example can be that Article 476 (3) of the Criminal Procedural Code of the Republic of Bulgaria, provides that "the Supreme Court of Cassation shall establish joint investigation team with other States with the participation of the Bulgarian prosecutor's office and investigation bodies. An agreement on the activities, conditions and composition of the joint investigation team shall be concluded with the competent authorities of the States Parties. We can see that the joint investigation team in the territory of the Republic of Bulgaria must comply with the provisions of international treaties, agreements and the legislation of Bulgaria [27]. Such norms can also be found in the criminal procedure codes of other countries of the European continent, such as the Republic of Slovenia, the Czech Republic, the French Republic, Estonia, the Slovak Republic.

The practice of recent years shows that the law enforcement agencies of the CIS member states have gradually begun to use inter-state investigation team in the investigation of crimes affecting the interests of several states.

Article 63 of Chisinau Convention (on Legal Assistance and Legal Relations in Civil, Family and Criminal Matters of October 7, 2002 of the Law No. 534) stipulates the procedure for the formation of joint operational and investigation teams and the conduct of interrogative actions.

According to it, Member States may establish joint investigation teams to conduct a thorough and comprehensive investigation of criminal cases committed by one or more persons in the territories of two or more Member States.

The formation of such a group is formalized in accordance with Article 60 of the Convention, which provides for the provision of legal assistance in criminal matters, with a decision to be made within 15 days from the date of receipt of the proposal to establish such a group [28].

Also, after the formation of a group between the member states of the treaty, a list of officials who will be included in this group will be provided.

Once an operational investigation team is established, the interactions between its members take place directly, they coordinate the main directions of the investigation, conduct interrogative actions, search operations, and the information obtained is directly shared (Article $63 \S 4$ of the Convention).

Also, Article 15 of the Law of the Republic of Uzbekistan "On operational search activities" stipulates that inquiries received on the basis of international agreements of the Republic of Uzbekistan on cooperation in the fight against crime and legal assistance are the basis for operational search activities [9].

Among the CIS countries, Article 578 of the CPC of the Republic of Kazakhstan and Article 571 of the CPC of Ukraine strengthen the norms on the establishment and operation of joint investigation groups.

International practice shows that the establishment of investigation teams is one of the most effective ways to provide mutual legal assistance. We can see that this experience opens a wide way for the development of actions such as full disclosure of international crimes, collection of evidence related to them and rapid exchange of information. In this regard, in her research, D.Umarkhanova proposes to adopt an international model agreement [1] on the establishment and regulation of investigative and operational investigation groups directly between the states within the UN. I think this proposal will definitely give a good result in the fight against and prevention of transnational crime.

The investigation activities are carried out in accordance with Law of the Republic of Uzbekistan No. 534, 26 August 2019 and it acceded to the Chisinau Convention on Legal Assistance and Legal Relations in Civil, Family and Criminal Matters of 7 October 2002. According to Article 3 of the Criminal Procedural Code, will be carried out in accordance with". Therefore, it would be expedient to amend the Criminal Procedural Code as follows:

Article $595^{1}$ Formation of joint investigation teams in the framework of international cooperation.

In case of violation of the interests of two or more states or protected by the laws of these states, the Prosecutor General's Office of the Republic of Uzbekistan, the investigation bodies of the Republic of 
Uzbekistan and the competent authorities of a foreign state on a temporary basis shall conduct joint investigation and operational search activities and may establish joint investigation teams.

The composition of a joint investigation, operational investigation teams is specified in a bilateral or multilateral agreement. The parties to the contract may change the member of the group nominated by the party with notice to all parties and with the consent of the parties.

\section{CONCLUSION}

In the development of information age, the implementation of existing and effective norms in the international arena into national legislation is in turn a manifestation of the country's comprehensive reforms. That is, the activities of investigation groups, which have a positive effect on international law, will further enhance the joint efforts of states to prevent a number of illegal actions or international crimes, such as threatening the rights of millions of people living on this land, threatening the economic potential of states.

\section{REFERENCES:}

1. Umarxanova, D.Sh. (2018) "Organization of the groups of investigation and operative investigation as a form of international cooperation on criminal cases," Review of law sciences: Vol. 2 , Article 10. p. $46-50$

2. https://undocs.org/ru/A/RES/40/32

3. https://www.unodc.org/documents/congress//Previous_Congresses/6th_Congress_1980/025_ACO NF.87.14.Rev.1_Sixth_United_Nations_Congress_on_the_Prevention_of_Crime_and_the_Treatment_of_ Offenders_R.pdf p.9-12

4. Bilenchuk P.D., Erkenov S.E., Kofanov A.V. Transnational Crime: State and Transformation / Edited by Acad. P.D. Bilenchuk. - K., 1999 .-- S. 145

5. Bozhelko O.A. On the problems of improving cooperation between the member states of the Commonwealth of Independent States in the fight against crime. Report from the Coordinating Council of Prosecutors General of the CIS Member States // Problems of prosecutorial and investigative practice. - 1999. - No. 1-2. -WITH. 59

6. 2002 EU Crime Report // http://www.europol.eu.int/index.asp?page=EUOrganisedCrimeSitRep2002\#JOINT\%20INVESTIGAT ION\%20TEAMS

7. Fisenko I.V. Prosecution System for International Crimes: Commissions of Inquiry and International Criminal Courts. // Belarusian Journal of International Law and International Relations. - 1998. - No. 4.

8. Agreement on the procedure for the creation and operation of a joint investigation team on the territories of the member states of the Commonwealth of Independent States dated October 16, 2015. // www.cis.minsk.by <http://www.cis.minsk.by>.

9. https://lex.uz/docs/2107763

10. Conny Rijken. 'Joint Investigation Teams: principles, practice, and problems Lessons learnt from the first efforts to establish a JIT' (2006) 2 (2) Utrecht Law Review 99.

11. Dubinsky A. Ya., Shostak Yu. I. Organization and activity of the investigative operational group: textbook. allowance. Kiev, 1981. P. 8-10.

12. Interaction of investigators with operatives of internal affairs bodies: method. manual / author. count .: L. M. Karneeva (leader) [and others]. M.: VNII MIA USSR, 1981. P. 79.

13. Bazhanov S.V. Group method of investigation as a way to improve the effectiveness of the preliminary investigation: dis. ... Cand. jurid. Sciences: 12.00.09. M., 1990. P. 38

14. Litvishko P.A. Creation and activity of joint investigative and operational groups // Russian investigator. 2010. No. 4. P.34-38.

15. Tsvetkov Yu.A. The principle of equality of legal force of evidence in international legal cooperation in criminal cases // International criminal law and international justice. 2013. No. 2. P. 7-10

16. http://docs.cntd.ru/document/420385655

17. https://www.un.org/ru/documents/decl_conv/conventions/orgcrime.shtml

18. https://www.un.org/ru/documents/decl_conv/conventions/corruption.shtml

19. https://www.lex.uz/acts/2068063

20. https://eurlex.europa.eu/LexUriServ/LexUriServ.do?uri=0J:C:2000:197:0001:0023:EN:PDF

21. https://eulaw.edu.ru/spisok-dokumentov-po-pravu-evropejskogo-soyuza/reshenie-soveta-ot-6aprelya-2009-g-o-sozdanii-evropejskogo-politsejskogo-vedomstva-evropol/

22. Gurbanov R.A. Subjects of cooperation of the judicial authorities of the EU member states in the field of criminal justice // Law and Politics. 2011. No. 9. P. 1500-1508. 
23. http://www.sobor.net/print.php?id_news=3991

24. Karaseva E.V. Procedural aspects of international cooperation of the preliminary investigation bodies of the Ministry of Internal Affairs of the Russian Federation. - M., 2000 .- P. 66.

25. https://www.legislationline.org/download/id/6793/file/Moldova_CPC_2003_am2016_en.pdf

26. https://www.legislationline.org/download/id/6416/file/Netherlands_CPC_am2012_en.pdf

27. https://www.legislationline.org/download/id/4152/file/PENAL_PROCEDURE_CODE_am2011_en.p df

28. http://www.cis.minsk.by/page/614

29. Fayziyev Shokhrud Farmonovich Medical law and features of legal relations arising in the provision of medical services. International journal of pharmaceutical research Volume 11, Issue 3, July - Sept, 2019 P. 1197-1200 doi:10.31838/ijpr/2019.11.03.088 http://www.ijpronline.com/ViewArticleDetail.aspx?ID=11016

30. Bryanskaya Elena, Fayziev Shokhrud, Altunina Anna, Matiukha Alena Topical Issues of an Expert Report in the Process of Proving in a Criminal Examination. International Journal of Engineering and Advanced Technology (IJEAT) ISSN: 2249 - 8958, Volume-9 Issue-1, October 2019 5345-5349 DOI: 10.35940/ijeat.A2946.109119 content/uploads/papers/v9i1/A2946109119.pdf

31. Fayziev Shokhrud (2019) Legal Aspects of Transplantology in the Republic of Uzbekistan. Systematic Reviews in Pharmacy, ISSN: 0976-2779, Vol: 10, Issue: 2, Page: 44-47 doi:10.5530/srp.2019.2.08 1575419211.pdf?1586863081

32. Tulaganova, G. Some issues of observance of international legal norms of fight against legalization of criminal incomes in the Republic of Uzbekistan Journal of Advanced Research in Dynamical and Control Systems 12 (2 Special Issue), c. 143-155

33. Bazarova D. Some problems of counteracting crimes related to laundering of illegal proceeds in Uzbekistan Journal of Advanced Research in Dynamical and Control Systems. Volume 11, Issue 7, 2019, Pages 873-885 